\title{
Development of a Multi-user System to Identify the Level of Attention in People
}

\author{
Alfredo Garcia ${ }^{1}$, Juan Manuel Gonzalez ${ }^{1}$, Amparo Palomino ${ }^{2}$ \\ ${ }^{1}$ Benemérita Universidad Autonoma de Puebla, \\ Facultad de Ciencias de la Computación, Puebla, Mexico \\ ${ }^{2}$ Benemérita Universidad Autonoma de Puebla, \\ Facultad de Ciencias de la Electrónica, Puebla, Mexico \\ alfredo_amigo18@hotmail.com,jumagoca78@gmail.com, \\ ampalomino@gmail.com
}

\begin{abstract}
The level of attention in people is associated with efficiency in their intellectual activities, in their level of understanding and in the development of their creative ability. The physiological variables with greater relevance in this application are the brain waves due to the cognitive relationship that exists between thinking and brain activity, therefore its implication is direct in this context. There are different techniques and systems described in the literature that are used to measure enumerable physiological variables related to the attention states of people. Some current limitations of these systems is that they only use a physiological variable and these systems are of the single-user type. In this paper an analysis of the state of the art is made with respect to the type of variables, techniques, instruments and types of systems used to measure the level of attention in people.
\end{abstract}

Keywords. Level attention, physiological variables, bio-feedback, brain waves, corporal posture.

\section{Introduction}

There are several disorders that affect the level of attention of people both in their childhood and adult-hood.

One of the most recognized disorders is the atten-tion deficit / hyperactivity disorder (ADHD) and is usually diagnosed for first time in the childhood; the symptoms persist in the adolescence and in the adulthood.

The ADHD is characterized by lack of attention, impulsivity and hyperactivity. Recently the ADHD has been estimated that affects $3.5 \%$ of school-age children around the world and is one of the most common psychiatric disorders among young people. Children with these problems are often unpopular and lack reciprocal friendships, but are not always aware of their own unpopularity. Although these 
symptoms tend to decrease with age, at least $50 \%$ of children with ADHD still have symptoms that de-crease in the adulthood.

Despite the vast literature that supporting the effi-cacy of stimulant medication in the treatment of the attention deficit / hyperactivity disorder (ADHD), several limitations of pharmacological treatments underscore the clear need for effective alternative psychosocial treatments.

To know the degree of affectation that ADHD produces in people, is necessary to have tools that can provide a feedback of the level of attention when the user is executing a specific task.

Currently there is a variety of commercial devices that quantitatively provide the level of concentration, meditation, relaxation and user attention, but generally are type mono-user, using a single physiological variable to obtain the final diagnosis. The performance of these devices is limited because they have restrictions by the manufacturer regarding the software and the hardware implemented.

Recent works describe various techniques to measure the level of attention in people (Digital im-age processing [1], Modification of the frequency range of binaural sounds [2], Wavelet Transform [3], Use of commercial tiaras [4], Classification of brain waves in emotions [5], Classification of text [10], among others, using different physiological variables such as: Facial gesturing [1, 7, 8], Brain waves [2, 3, 4, 5, 6, 9, 36, 37], Body gesturing [8], body posture [8], cardiac pulses [8], respiratory rate $[8,24]$, way of write a text [10], sight trajectory [25], movement of the head [32], spit $[8,31]$, sweat $[8,31]$, temperature $[8,31,40]$, glucose in blood $[31,39]$ and gesticula-tion in the hands [41].

However, there is still a lack of a system that in-volves more than one physiological variable, which generates more hardiness in the system and consequently provides a diagnosis with greater reliability of the level of attention in the user.

In the literature has been verified that the vast majority of reported works are type mono-user, which generates a restriction only to be applied in an isolated context and not in a real social environment such as a classroom.

In this research work is proposed a model to develop a system to measure the level of attention in people, using at least 2 physiological variables, implementing a multiuser system and generating a feedback in the form of a closed loop to carry out some action that helps to restore the user's level of attention.

\section{State of the Art Analysis}

The variety of techniques applied in the field of research to quantify the level of attention of people leads toward a descriptive analysis that is presented in this work.

\subsection{Acquisition Techniques of Physiological Variables Related to the Attention Status of People}

Starting from the review in the literature of the variables used to relate the level of 
attention in people, has been found that the brain waves are the physiological variables with greater relevancy due to the cognitive relationship that exists between think-ing and brain activity. Therefore its implication is direct.

The graph of the Figure 1 shows the relevance that each one of the physiological variables has on the level of attention of the people. This analysis is ob-tained from the state of the art of the related works.

Depending on the physiological variable used, the device is chosen to perform the data acquisition. Within the most devices used in the literature are: the electroencephalogram, WEB cam, motion sensors, gyroscopes, electrodes, mouse, electrocardiogram, electrochemical sensors, keyboard, transducers, cam-eras and optical sensors.

\section{Physiological variables in the literature}

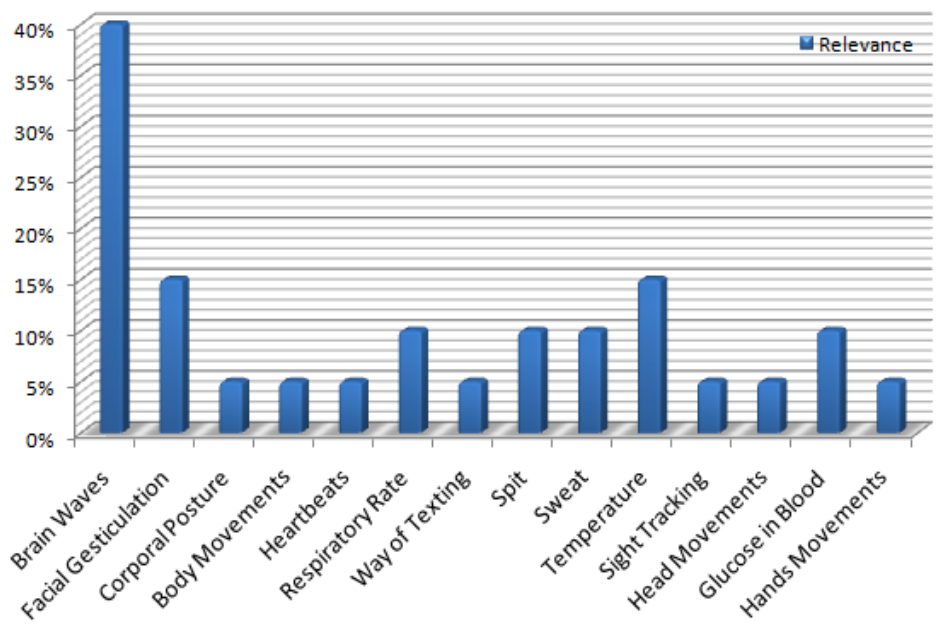

Fig. 1. Relevance of the physiological variables related to the level of attention in the literature.

The Figure 2 shows the relationship between the devices used to obtain the data and the physiological variable sensed.

The techniques applied to obtain the data of the physiological variables also play a fundamental role since the effectiveness of the final diagnosis depends on them. The tables 1 and 2 describe a comparison of various data acquisition techniques and their components as a physiological variable, device and software employees, sampling time, effectiveness and relationship with levels of attention.

\subsection{Feedback Techniques Applied on the Attention Status of People}

Once the level of attention of the user is known, is necessary to exert some action that gives feedback to the user to stimulate his concentration in the activity or task that he is carrying out.

In the literature has been found that studies related to the classroom showed that 
environmental factors, such as cognitive assistance technology (CAT), can help people with cognitive disabilities [27].

An example is the battery of the attention training system. This electronically generated response cost system is placed on a student's desk and handled with a remote control that is given to the teacher. It is designed to send comments in order to increase the levels of attention related to tasks. This system was more effective compared to a pre-existing classroom management program that used chip reinforcement [27]. Another example is the watchminder, a vibrat-ing wristwatch. This self-monitoring device aims to increase the task behavior of elementary school children. The results of this study proved effective for two of each three participants.

The graph of the Figure 3 shows the most used feedback systems to stimulate the attention status of people in general. In this comparative analysis is ob-served that visual learning environments are the most common tool in the area of cognitive sciences.

\section{SIGNALS ACQUISITION}

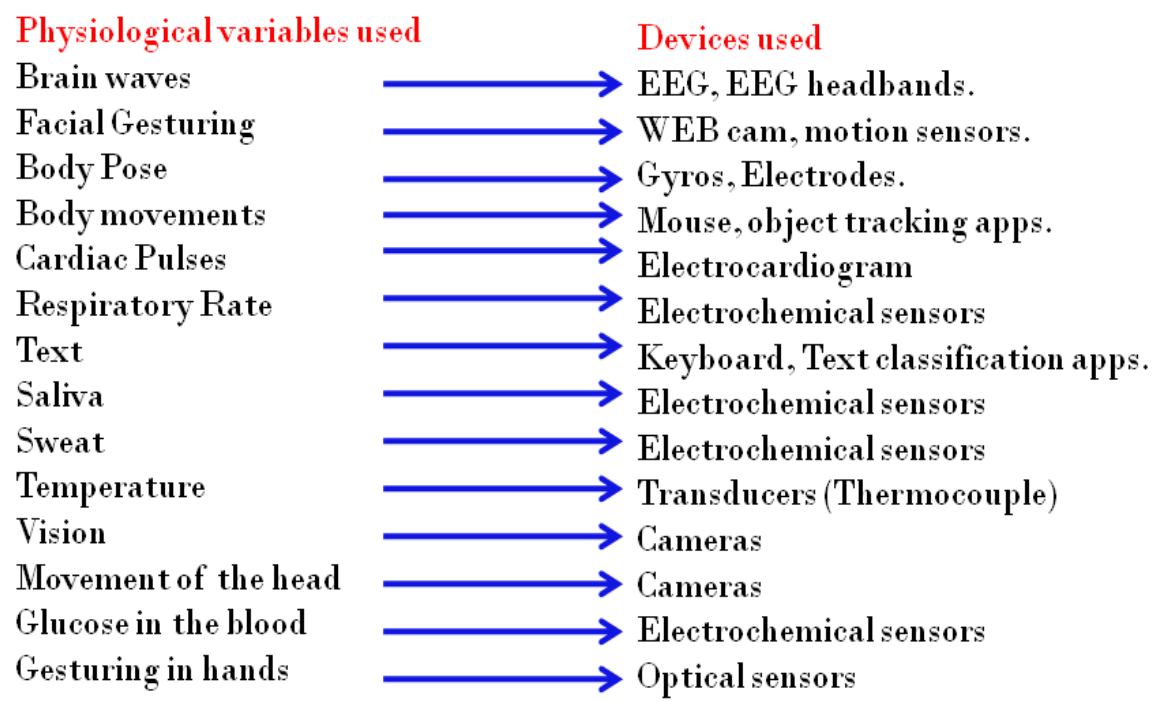

Fig. 2. Devices used to obtain the data of the physiological variable sensed.

\section{Construction of the Model for Identifying the Level of Attention in People}

In the literature has been found that biofeedback training systems induce a specific mental or physical state in a user through a closed cycle of bio-feedback. These systems gather the physiological state of a person through the detection of hardware, integrate this state into a computer-based interactive system and present the comments so that the user can work to adjust their status $[19,20,26]$. 
Table 1. Comparison of physiological variables, techniques and relation with the levels of attention.

\begin{tabular}{|c|c|c|c|}
\hline $\begin{array}{l}\text { Reference } \\
\text { Number }\end{array}$ & $\begin{array}{l}\text { Physiological } \\
\text { variable used }\end{array}$ & Technique applied & $\begin{array}{l}\text { Relationship and impact } \\
\text { with the levels of attention }\end{array}$ \\
\hline 1 & $\begin{array}{c}\text { Facial } \\
\text { Gesticulation }\end{array}$ & Digital image processing & $\begin{array}{l}\text { The automated recognition } \\
\text { of emotions can be directly } \\
\text { correlated with the levels of } \\
\text { attention of a teenager. }\end{array}$ \\
\hline 2 & $\begin{array}{l}\text { Binaural waves } \\
\text { (auditory waves) }\end{array}$ & $\begin{array}{l}\text { Modification of the } \\
\text { frequency range of the } \\
\text { incident waves }\end{array}$ & $\begin{array}{c}\text { Binaural waves cause a } \\
\text { positive impact on mental } \\
\text { states such as active } \\
\text { concentration and creative } \\
\text { visualization. }\end{array}$ \\
\hline 3 & $\begin{array}{l}\text { Brain waves (Alfa, } \\
\text { Beta, Delta, Theta } \\
\text { y Gamma) }\end{array}$ & Wavelet Transform & $\begin{array}{c}\text { Use of the Mindwave } \\
\text { headband for reading brain } \\
\text { signals, which are classified } \\
\text { in levels of attention }\end{array}$ \\
\hline 4 & $\begin{array}{c}\text { Brain waves } \\
\text { produced by facial } \\
\text { gestures }\end{array}$ & $\begin{array}{l}\text { Suites of EmotivEpoc: } \\
\text { *Affective , *Expressiv, } \\
\text { *Cognitiv }\end{array}$ & $\begin{array}{l}\text { Use of the EmotivEpoc } \\
\text { headband for the reading of } \\
\text { brain signals, which are } \\
\text { classified in levels of } \\
\text { attention. }\end{array}$ \\
\hline 5 & $\begin{array}{l}\text { Brain waves (Alfa, } \\
\text { Beta, Delta, Theta } \\
\text { y Gamma) }\end{array}$ & $\begin{array}{l}\text { Classification of brain } \\
\text { waves in emotions } \\
\text { through their frequency } \\
\text { variations }\end{array}$ & $\begin{array}{l}\text { The automated recognition } \\
\text { of emotions can be directly } \\
\text { correlated with the levels of } \\
\text { attention of a teenager }\end{array}$ \\
\hline 6 & $\begin{array}{l}\text { Brain waves (Alfa, } \\
\text { Beta, Delta, Theta } \\
\text { y Gamma) }\end{array}$ & $\begin{array}{l}\text { Bayesian classification } \\
\text { and Hill Climbing search } \\
\text { algorithm }\end{array}$ & $\begin{array}{l}\text { The automated recognition } \\
\text { of emotions can be directly } \\
\text { correlated with the levels of } \\
\text { attention of a teenager. }\end{array}$ \\
\hline 7 & $\begin{array}{l}\text { Brain waves (Alfa, } \\
\text { Beta, Delta, Theta } \\
\text { y Gamma) }\end{array}$ & $\begin{array}{l}\text { Digital image processing } \\
\text { Affective computing }\end{array}$ & $\begin{array}{c}\text { Automatic feedback can } \\
\text { improve levels of } \\
\text { adolescent care. }\end{array}$ \\
\hline 8 & $\begin{array}{l}\text { Facial gesturing } \\
\text { Body movements }\end{array}$ & $\begin{array}{l}\text { Digital image processing } \\
\text { Mouse movement }\end{array}$ & $\begin{array}{l}\text { Application of tasks that } \\
\text { require cognitive processes } \\
\text { such as attention, memory } \\
\text { and reasoning. }\end{array}$ \\
\hline 9 & $\begin{array}{l}\text { Brain waves } \\
\text { Heart waves }\end{array}$ & $\begin{array}{c}\text { Characterization of signal } \\
\text { changes } \\
\text { Classification of brain and } \\
\text { heart waves in emotions } \\
\text { through their frequency } \\
\text { variations }\end{array}$ & $\begin{array}{l}\text { The automated recognition } \\
\text { of emotions can be directly } \\
\text { correlated with the levels of } \\
\text { attention of a teenager. }\end{array}$ \\
\hline 10 & Text & $\begin{array}{l}\text { E-learning (Identification } \\
\text { of emotions through the } \\
\text { way of writing a text) }\end{array}$ & $\begin{array}{l}\text { The automated recognition } \\
\text { of emotions can be directly } \\
\text { correlated with the levels of } \\
\text { attention of a teenager. }\end{array}$ \\
\hline
\end{tabular}


Alfredo Garcia, Juan Manuel Gonzalez, Amparo Palomino

Table 2. Comparison of devices, Software, Sampling time and effectiveness in relation with the levels of attention.

\begin{tabular}{|c|c|c|c|c|}
\hline $\begin{array}{l}\text { Reference } \\
\text { Number }\end{array}$ & Device used & Software & $\begin{array}{c}\text { Sampling } \\
\text { time }\end{array}$ & Effectiveness \\
\hline 1 & $\begin{array}{l}\text { Web Cam Logitech } \\
\text { C170 USB } 2.0\end{array}$ & $\begin{array}{l}\text { Open CV } \\
\text { Cmake }\end{array}$ & $\begin{array}{c}1 \text { frame / } \\
64.93 \\
\text { milliseconds }\end{array}$ & $\begin{array}{c}\text { Average detection } \\
\text { rate: } 84 \%\end{array}$ \\
\hline 2 & Headset headband & $\begin{array}{c}\text { Visual Studio } \\
\mathrm{C}++\end{array}$ & Not specified & $\begin{array}{c}\text { Efficiency of } \\
\text { binaural sounds: } \\
80 \%\end{array}$ \\
\hline 3 & $\begin{array}{l}\text { Bluetooth RFCOMM6 } \\
\text { Headband Mindwave }\end{array}$ & Matlab & $\begin{array}{l}\text { Sampling } \\
\text { frequency: } \\
512 \mathrm{~Hz}\end{array}$ & Not specified \\
\hline 4 & $\begin{array}{l}\text { Headband Emotive } \\
\text { Epoc }\end{array}$ & $\begin{array}{l}\text { Labview } \\
2010\end{array}$ & Not specified & $\begin{array}{l}60 \% \text { writing } \\
\text { efficiency using the } \\
\text { BCI (Brain } \\
\text { Computer } \\
\text { Interface) }\end{array}$ \\
\hline 5 & $\begin{array}{c}\text { Arduino Uno } \\
\text { Casco de electrodos }\end{array}$ & JAVA C\# & Not specified & Not specified \\
\hline 6 & $\begin{array}{l}\text { Headband Emotive } \\
\text { Epoc }\end{array}$ & $\begin{array}{l}\text { WEKA } \\
\text { Wizard }\end{array}$ & $\begin{array}{c}2048 \mathrm{~Hz} \\
56 \text { data / } \\
\text { image }\end{array}$ & $\begin{array}{l}\text { Stays correctly } \\
\text { classified: } \\
53.7879 \%\end{array}$ \\
\hline 7 & $\begin{array}{l}\text { WEB CAM of PC used } \\
\text { for experiment } \\
\text { (variable) }\end{array}$ & $\begin{array}{l}\text { JAVA WEB } \\
\text { PHP }\end{array}$ & Not specified & $\begin{array}{l}\text { Accuracy in the } \\
\text { recommendation } \\
\text { system: } \\
5,757 \%\end{array}$ \\
\hline 8 & $\begin{array}{l}\text { WEB CAM of PC used } \\
\text { for experiment } \\
\text { (variable) }\end{array}$ & $\begin{array}{c}\text { Face } \\
\text { Tracking } \\
\text { SDK Kinect } \\
\text { for } \\
\text { Windows. }\end{array}$ & Not specified & Not specified \\
\hline 9 & $\begin{array}{l}\text { Electroencephalogram } \\
\text { Electrocardiogram } \\
\text { Prototyping data } \\
\text { acquisition card }\end{array}$ & $\begin{array}{l}\text { Prototyping } \\
\text { software }\end{array}$ & Not specified & Not specified \\
\hline 10 & $\begin{array}{c}\text { PC used for } \\
\text { measurement (variable) }\end{array}$ & $\begin{array}{l}\text { Word NET } \\
\text { Word NET } \\
\text { Affect }\end{array}$ & Not specified & Not specified \\
\hline
\end{tabular}




\section{Feedback systems in the Literature}

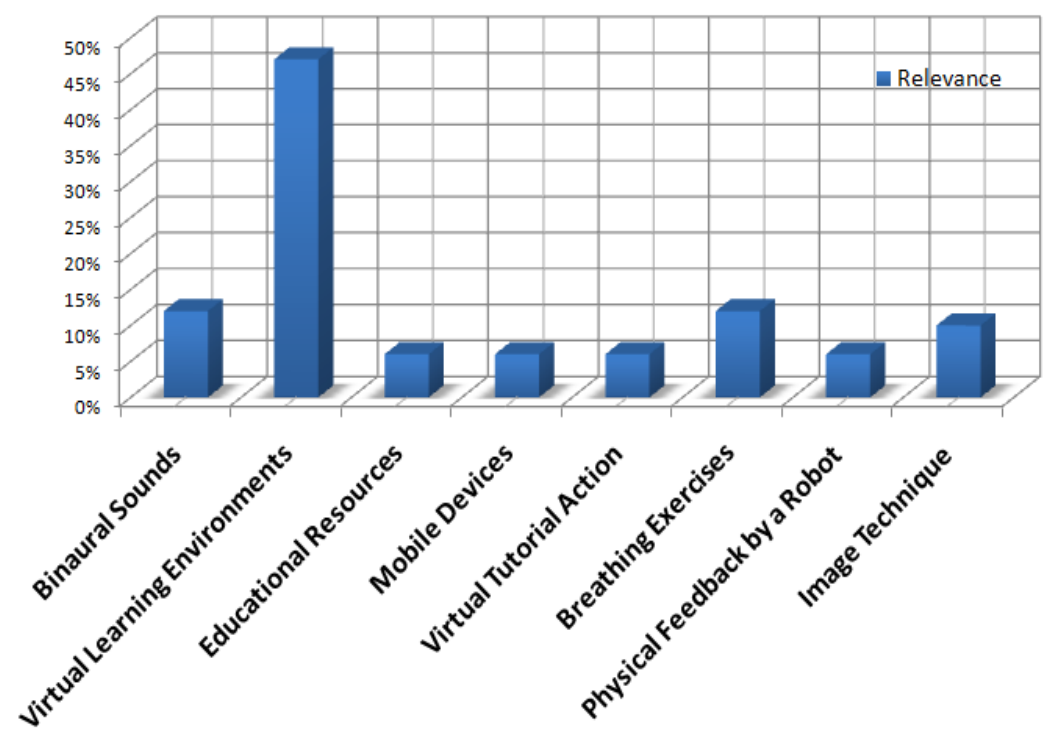

Fig. 3. Relevance of the feedback systems related to the level of attention in the literature.

\subsection{Type of Model}

For this reason the closed-loop control technique (shown in Figure 4) has been proposed in this work, where the input variables will be the signals of the physiological variables, the output signal will be the feedback that is sent to the user in an automated way, The system floor will be the user whose function is to selfregulate their attention and concentration depending on the feedback received by the system.

\subsection{Selected Physiological Variable}

According to the relevance of the physiological variables mentioned in the literature, brain waves have been chosen as the main parameter to measure the level of attention of a person.

Body posture has been proposed as a second phy-siological variable, in [8] is placed on its relationship with the state of attention as psycho-educational support in virtual learning environments, this case presenting a development challenge that has not been solved in this context.

\subsection{Validation Instruments}

These measurement techniques should be available in the language of the participants and should measure the main aspects of cognitive rehabilitation. For example, to 
evaluate the improvements of attention in longitudinal studies, the following scales and questionnaires could be used: Integrated Visual and Auditory Continuous Performance Test (VAT), Test of Variable Attention (TOVA), among others [20].

\subsection{Data Acquisition}

According to the physiological variables selected and supported by the reviewed literature, the information collection instruments will be adapted commercial sensors that obtain the measurement of the selected physiological variables, the reading of these signals will be obtained by the system implemented and sent wirelessly to a computer where the processing, classification and feedback of the automated system will be carried out.

\section{$4 \quad$ Limitations and Experimental Advances}

This section describes the research work and experi-mental work carried out so far. The work planned in the future is also mentioned.

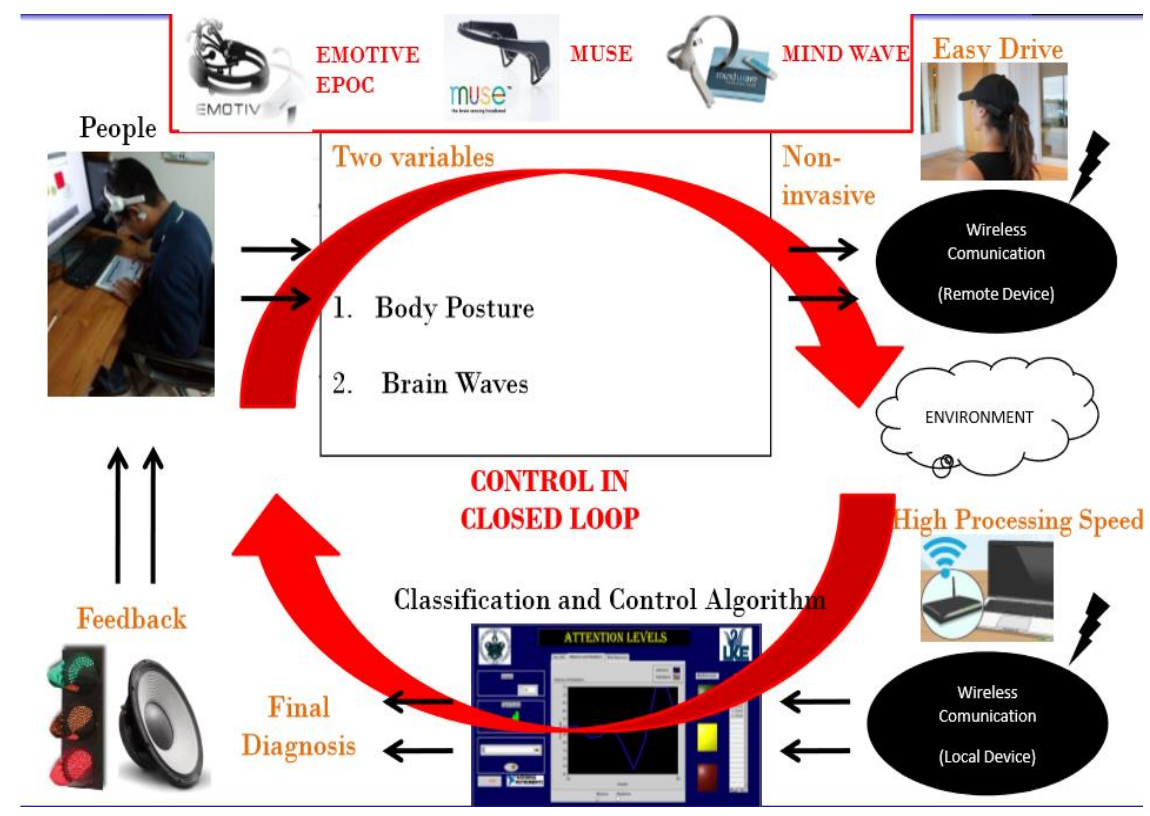

Fig. 4. Model of the closed-loop control technique applied to the attention system.

\subsection{Limitations}

In the implementation of the works $[2,5,7,8,11,12,14,15,19,21,23,24,25,27$, $28,29,30]$ re-viewed so far, systems have been developed of mono-user type, which represents a development challenge towards multi-user systems in this context. 
Another limitation that has been found in the literature is the use of a single physiological variable in most of the works $[2,5,7,8,11,12,14,15,19,21,23,24]$ presented, which also represents a challenge on the robustness of the systems in this context.

\subsection{Experimental advances}

In the first instance, experimental tests were car-ried out using the MindWave commercial device of the Neurosky company, to detect the level of atten-tion in first semester students of the computer degree of the BUAP. A sample of 22 students whose ages are between 17 and 22 years old was used.

To obtain the data of the brain signals, a mono-user system was implemented, using the LABVIEW software. Figure 5 illustrates the graphical interface where you can observe the behavior of the brain sig-nals, a traffic light as feedback, a vector where are saved the sampled data and the variation of the user's level of attention.

The test was carried out in two modalities: with tablet and desktop computer. The practical development is shown in figure 6 .

With the data obtained an analysis is made and is shown in the graph of Figure 7, which reflects higher concentration reached by users when handling a tab-let than by manipulating the mouse of a desktop computer, which indicates that the device mouse influences as a distractor agent when executing a specific task.

A second experiment was carried out in the labora-tory of the Computation faculty of the BUAP, where 12 undergraduate students were integrated into 3 teams. The activity to be carried out consisted of developing ideas for a science project in an organized way, where each team member participated actively in its elaboration.

While the activity was being carried out, 5 students were randomly monitored, where their attention level was obtained for 10 minutes, the feedback was ob-served in another independent room through a physi-cal traffic light and a laptop where they received the data sensed with the MindWave diadem, which de-scribed the student's level of attention in each sam-pling.

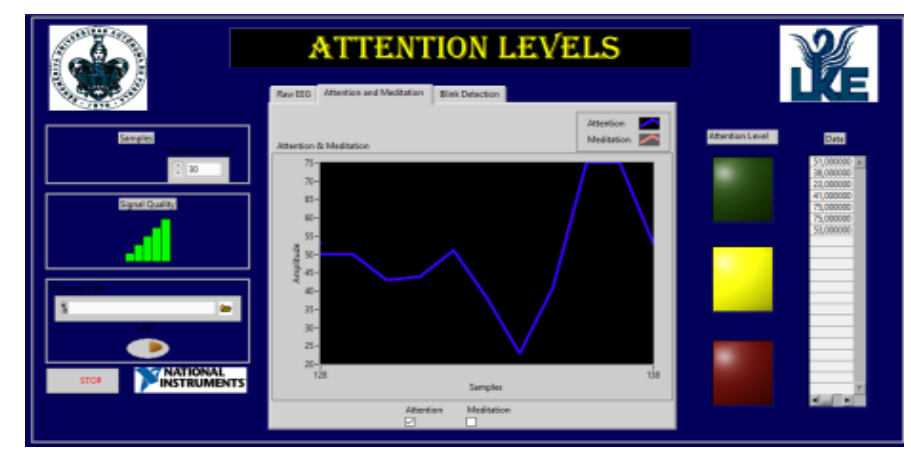

Fig. 5. Graphical interface implemented in LABVIEW. 


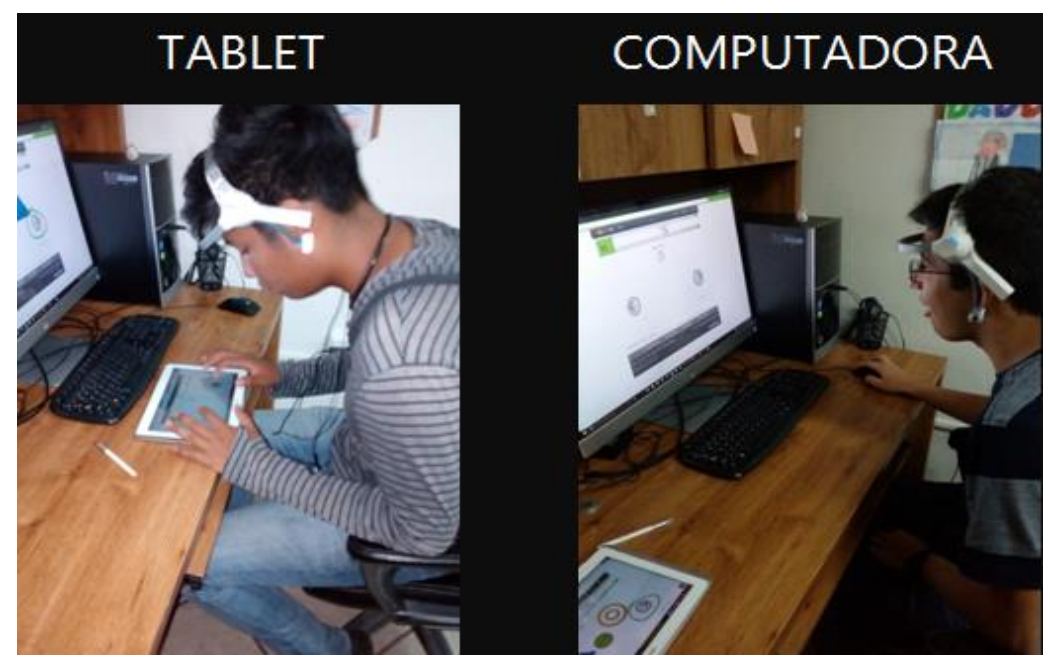

Fig. 6. Graphical interface implemented in LABVIEW.

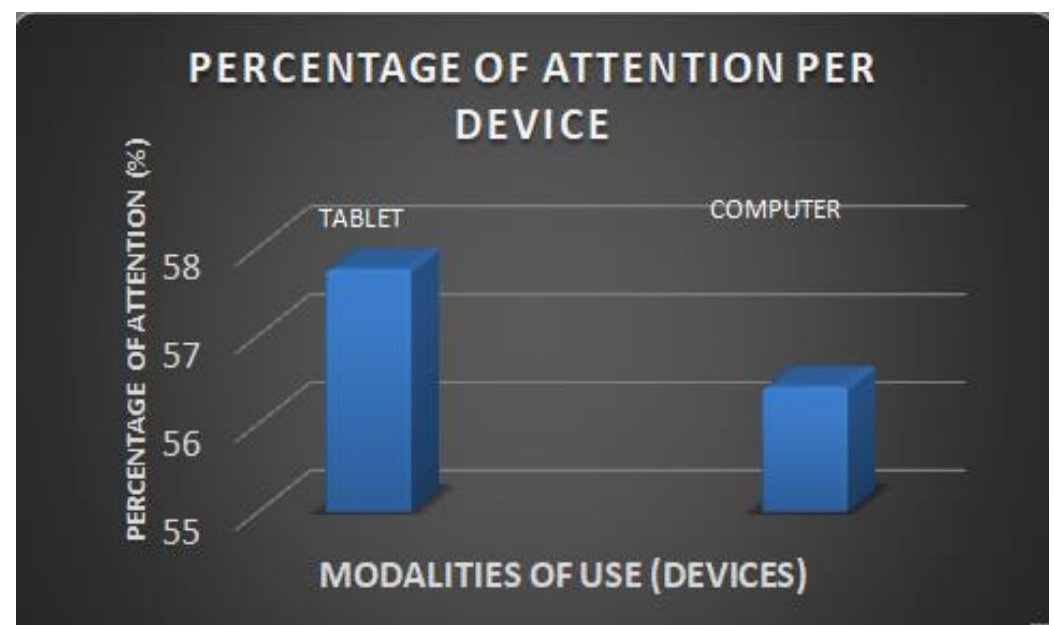

Fig. 7. Percentage of attention per device.

Table 3. Level of attention in the monitored students.

\begin{tabular}{cc}
\hline Student & Attention Level (\%) \\
\hline Ruben & 57.39 \\
Fernando & 45.36 \\
Marcos & 60.98 \\
Melani & 52.77 \\
Noé & 48.35 \\
Global Average & $\mathbf{5 2 . 9 7}$
\end{tabular}


The samples were taken every 500 milliseconds with an instantaneous feedback to the person who monitored the activity in an isolated room. The average of the samples of each monitored student is shown in the Table 3 and in the Figure 8.

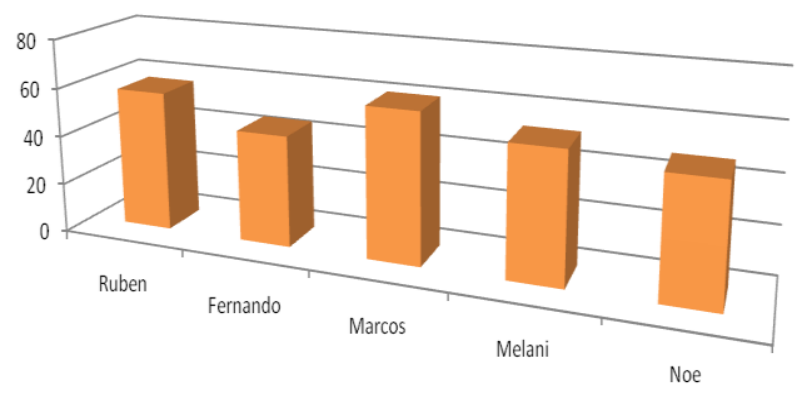

Fig. 8. Graph of the level of attention in the monitored students.

As a continuation of the work, the use of other com-mercial devices was validated in order to compare their performance.

For this motive 3 attention monitors were imple-mented using the three commercial headbands with the highest number of mentions in the literature: Muse, Emotiv Epoc and Neurosky. At first, the soft-ware of each manufacturer is explored and subse-quently a system of transmission and reception of information is implemented to obtain the data read by the sensors, sending them to an own interface to be processed freely.

The software developed by the manufacturer Inte-raxon, provides direct access to the data read by the Muse brain sensor, this feature allows to perform a better interaction with the device and is used to de-velop a mono-user data acquisition interface, shown in figure 9, which has a panel to visualize the level of attention of the user, 1 virtual traffic lights and 1 table where the numerical data of the user's attention level is displayed in an approximate time to the real time.

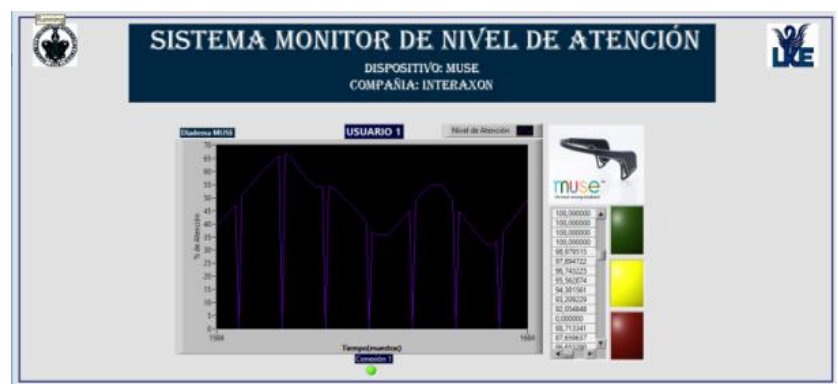

Fig. 9. Muse attention monitor implemented in Labview.

The software developed by the manufacturer Emotiv Systems, provides direct access to the data read by the brain sensor Emotive Epoc, this feature allows a better 
interaction with the device and is used to de-velop a single-user data acquisition interface, which It is shown in Figure 10, which has 1 panel to display the user's attention level, 1 virtual traffic lights and 1 table where the numerical data of the user's attention level is displayed in an approximate time to the real time.

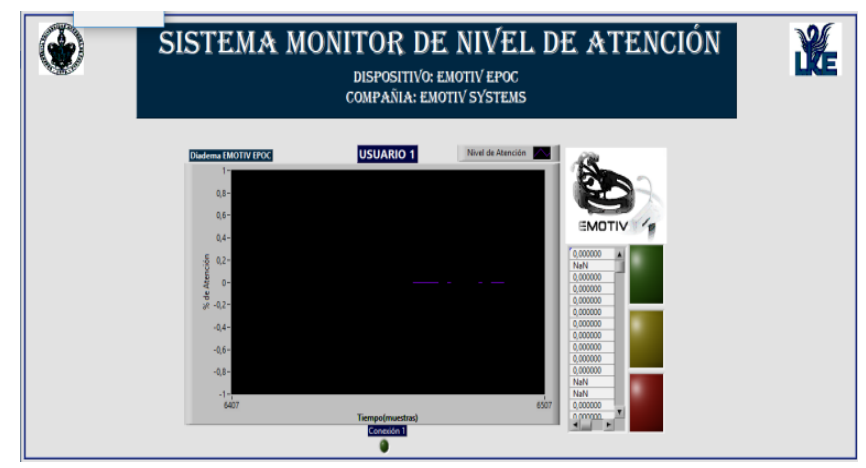

Fig. 10. Emotiv EPOC attention monitor implemented in Labview.

The software developed by the manufacturer Neu-roSky, provides direct access to the data read by the brain sensor MindWave, this feature allows to per-form a better interaction with the device and is used to develop a multi-user data acquisition interface, which is shown in figure 11 , which has 2 panels to visualize the level of attention of each user, 2 virtual traffic lights and 2 tables where the numerical data of the level of attention of each user is displayed in a time approximated to the real time.

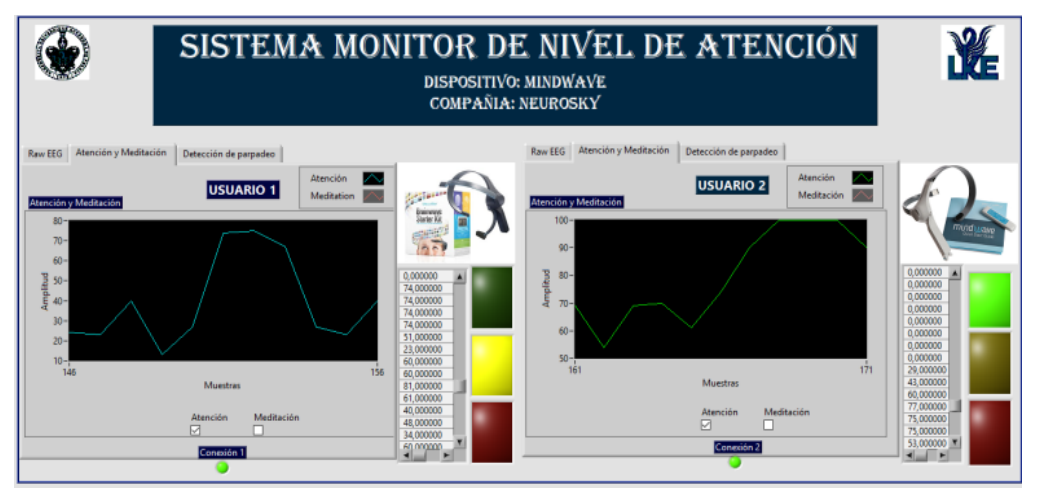

Fig. 11. MindWave attention monitor implemented in Labview.

\section{Conclusions}

The implementation of single-user systems and the use of a single physiological variable are 2 of the main limitations that have been found in the literature in the context of the systems used to measure the attention of people. 
Based on these limitations, the first implementa-tion of a single-user type system was performed, us-ing brain waves as the only physiological variable.

In the second experiment is shown that the level of attention in students when working as a team is on average $53 \%$, only $3 \%$ above the expected half, this is due that diverse factors influence a collaborative context, where there is noise, diversity of opinions and other distractors that divert the attention more easily than in a controlled environment where con-centration is stimulated individually.

As a continuation of the work, a data acquisition system is made for 3 different headbands, where a multi-user system with the Mindwave device of the Neurosky company was efficiently implemented.

As a future direction of this research work, has been proposed to correlate a second physiological variable with the attention states and increase the number of users in the system.

\section{References}

1. Marín, E.J.: Detección de emociones del usuario. Tesis Pontificia Universidad Católica de Valparaíso, volumen 1, Chile, 1- 67 (2014)

2. Domínguez, C.: Las Ondas Binaurales y sus Efectos. Tesis de Investigación Experimental volumen 1, Ciudad Cooperativa Cruz Azul, 1- 22 (2015)

3. Torres, F., Sánchez, C., Palacio, B.: Adquisición y análisis de señales cerebrales utilizando el dispositivo MindWave. MASKANA, I+D+ingeniería 2014, volumen 1, 1-11 (2014)

4. Rojas, S., Garzón, J., Martínez, D., Escobar, M., Robayo, C.: Lector de ondas cerebrales para implementar un sistema alternativo y aumentativo de comunicación. In Proceedings 10th Latin American and Caribbean Conference for Engineering and Technology, volumen 10, 1-9 (2012)

5. Campazzo, E., Martínez, M., Guzmán, A., Agüero, A.: Desarrollo de interface de detección de emociones para su utilización en redes sociales y entornos virtuales de aprendizaje. In Proceedings XV Workshop de Investigadores en Ciencias de la Computación, volumen 1,Paraná , 1-5 (2013)

6. García, A.E.: Análisis de ondas cerebrales para determinar emociones a partir de estímulos visuales.Universidad Veracruzana Facultad de Estadística e Informática, volumen 1, Xalapa, Veracruz, México, 1-137 (2015)

7. Hernández, A., Vásquez, R., Olivares, B.A., Cortes, G., López, I.: Sistema de detección de emociones para la recomendación de recursos educativos. Programación Matemática y Software, 8(1), 58-66 (2016)

8. Saneiro, M.M.: Apoyo psico-educativo y afectivo en entornos virtuales de aprendizaje. Badajoz, International Journal of Developmental and Educational Psychology, volumen 1, numero 2, España, De INFAD Base de datos, 233-241 (2015)

9. Campazzo, E., Martinez, M., Guzmán, A.E., Agüero, A.: Entornos Virtuales de Aprendizaje integrado a tecnología móvil y detección de emociones. Secretaría de Ciencia y Tecnología/Departamento de Ciencias Exactas Físicas y Naturales/Universidad Nacional de La Rioja, volumen 1, La Rioja, 1-5 (2015)

10. Aballay, L., Aciar, S., Reategui, E.: Propuesta de un Método para Detección de Emociones en E-Learning. In Proceedings ASAI 2015, $16^{\circ}$ Simposio Argentino de Inteligencia Artificial, Porto Alegre, Brasil, 121-128 (2015)

11. Garcia, A., Muñoz, M., Suarez, C.: Gestión de emociones en espacios virtuales de formación. Investigación Educativa, 12,(21), Salamanca, España, 45-65 (2008) 
12. Aymerich-franch, L.: Los juegos en entornos virtuales como herramientas de aprendizaje: estudio de la respuesta emocional de los participantes. SPHERA PÚBLICA Revista de Ciencias Sociales y de la Comunicación, 12(12), Murcia, España, 183-197 (2012)

13. Hernández, A.M.: Aprendizaje Electrónico Afectivo: un modelo Innovador para Desarrollar una Acción Tutorial Virtual de Naturaleza Inclusiva. Formación Universitaria Volumen 8(2), Granada, España, 19-26 (2015)

14. Desney, S.T., Nijholt, A.: Brain-computer interfaces. Springer, London Dordrecht Heidelberg, volumen 1, New York, USA, 1-275 (2010)

15. Regan, L.M., Shane, D., Kalyn, R.M., Bertram, P.C., Gaetz, M., Doucette, A., Taylor, B.A., Orr, A.P., Keiver, K.: Games as neurofeedback training for children with FASD. In Proceedings IDC '13 Proceedings of the 12th International Conference on Interaction Design and Children, volumen 1, New York, USA, 165-172 (2013)

16. Pascual, M.F., Begoña, Z., Buldian, K.M.: Adaptive cognitive rehabilitation interventions based on serious games for children with ADHD using biofeedback techniques: assessment and evaluation. In Proceedings COMPUTE '10 Proceedings of theThirdAnnual ACM Bangalore Conference, article 29, Bilbao, España, 1-4 (2010)

17. Beaton, R., Merkel, R., Prathipati, J., Weckstein, A., McCricard, S.: Tracking mental engagement: a tool for young people with ADD and ADHD, In Proceedings ASSETS '14 Proceedings of the 16th international ACM SIGACCESS conference on Computers \& accessibility, volumen 1, Virginia, USA, 279-280 (2014)

18. Sonne, T., Jensen, M.M.: Evaluating the ChillFish Biofeedback Game with Children with ADHD. In Proceedings IDC '16 Proceedings of The 15th International Conference on Interaction Design and Children, volumen 1, New York, USA, 529-534 (2016)

19. Sonne, T., Jensen, M.M.: ChillFish: A Respiration Game for Children with ADHD. In Proceedings of the TEI '16: Tenth International Conference on Tangible, Embedded, and Embodied Interaction, volumen 1, New York, USA, 271-278 (2016)

20. Asiry, O., Shen, H., Calder, P.: Extending Attention Span of ADHD Children through an Eye Tracker Directed Adaptive User Interface. In Proceedings ASWEC '15, Vol. II Proceedings of the ASWEC 2015 24th Australasian Software Engineering Conference, volumen 1, Australia, 149-152 (2015)

21. Divia, V.: FOQUS: A Smartwatch Application for Individuals with ADHD and Mental Health Challenges. In Proceedings ASSETS '16 Proceedings of the 18th International ACM SIGACCESS Conference on Computers and Accessibility, volumen 1, Nevada, USA, 311312 (2016)

22. Zuckerman, O., Hoffman, G., Rubin, D.K., Klomek, A.B., Shitrit, N., Amsalem, Y., Shlomi, Y.: KIP3: Robotic Companion as an External Cue to Students with ADHD. In Proceedings of the TEI '16: Tenth International Conference on Tangible, Embedded, and Embodied Interaction, volumen 1, New York, USA, 621-626 (2016)

23. Kang, H.W., Zentall, S.S., Burton, T.L.: Use of images in instructional technology for children with attentional difficulties. In Proceedings IDC '07 Proceedings of the 6th international conference on Interaction design and children, volumen 1, New York, USA, 129-132 (2007)

24. McLaren, E.S., Antle, A.N.: Exploring and Evaluating Sound for Helping Children SelfRegulate with a Brain-Computer Application. In Proceedings IDC '17 Proceedings of the 2017 Conference on Interaction Design and Children, volumen 1, California USA, 393-398 (2017)

25. Weisberg, O., Galoz, A., Berkowitz, R., Weiss, N., Peretz, O., Azoulai, S., Rubin D.K., Zuckerman, O.: TangiPlan: designing an assistive technology to enhance executive functioning among children with ADHD. In Proceedings En IDC '14 Proceedings of the 2014 conference on Interaction design and children, volumen 1, New York, USA, 293-296 (2014) 
26. Bandodkar, A.J. Wang, J.: Non-invasive wearable electrochemical sensors: a review. Trends in Biotechnology, volumen 32, número 7, San Diego, USA, 363-371 (2014)

27. Maimó, M.F., Mackenzie, I.S., Yee, C.M. Varona, J.: Evaluating Fitts' Law Performance With a Non-ISO Task. In Proceedings of Interacción '17, volumen 1, Cancún, Mexico, 1-8 (2017)

28. Perakakis, M. Potamianos, A.: An Affective Evaluation Tool Using Brain Signals. IUI'13 Companion, volumen 1, USA, 105-106 (2013)

29. Pinto, R.D. Ferreira, H.A.: Development of a Non-invasive Brain Computer Interface for Neurorehabilitation. REHAB '15, volumen 1, Lisbon, Portugal, 1-5 (2015)

30. Eadie, M., Steele, R.J.: Non-invasive Blood Glucose Monitoring and Data Analytics, ICCDA '17, volumen 1, Florida, USA, 138-142 (2017)

31. Blank, M. Sinclair, M.: Demo: Non-invasive and long-term core temperature measurement. SenSys'11, volumen 1, Seattle, USA, 1-2 (2011)

32. Avila, S.O., Rakona, B., Mistry, P.: Non-invasive optical detection of hand gestures. AH '15, volumen 1, Singapur, Singapur, 179-180 (2015) 